
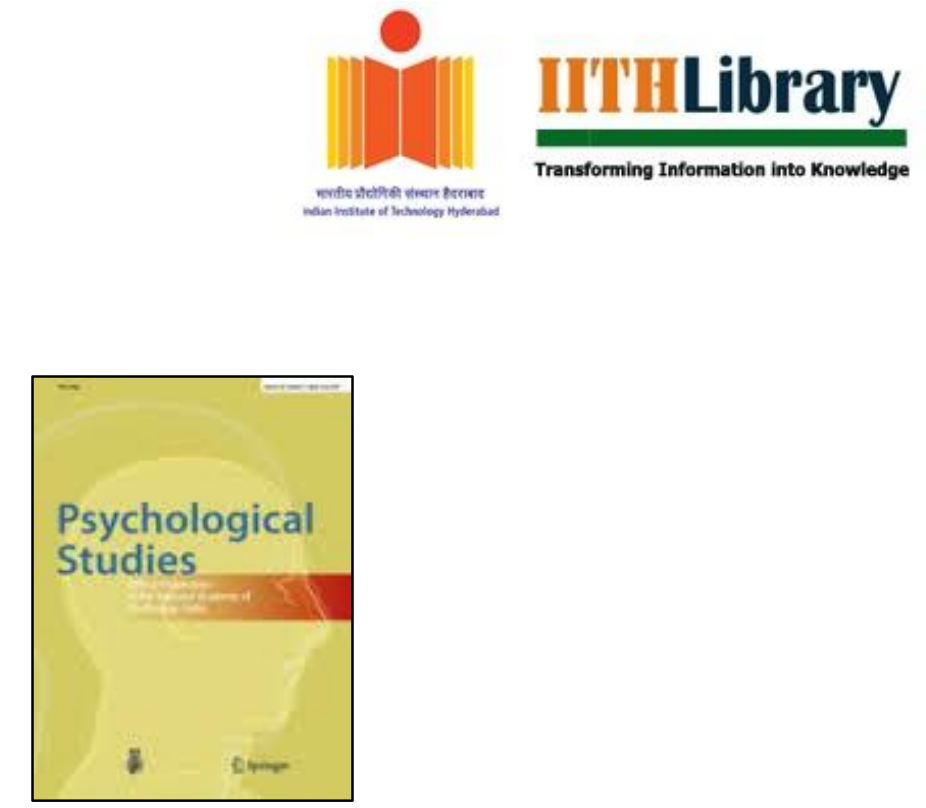

\title{
From Victimhood to Survivor-Hood: Reflections on Women's Agency in Popular Films on Sex Trafficking in India
}

\author{
Nisha James, Shubha Ranganathan \\ - $\quad$ Department of Liberal Arts, Indian Institute of Technology, Hyderabad, India \\ G-49, Girls Hostel, Indian Institute of Technology Hyderabad, Yeddumailaram, Medak, 502205, Telangana, India \\ Faculty cabin no. 210, E block, Indian Institute of Technology Hyderabad, Yeddumailaram, Medak, 502205, Telangana, India
}

\section{Psychological Studies}

Accepted author version

http://dx.doi.org/10.1007/s12646-015-0344-4

This is author version pre-print archived in the official Institutional Repository of IITH http://www.iith.ac.in/

From victimhood to survivor-hood: Reflections on women's agency in popular films on sex trafficking in India

\begin{abstract}
Crimes against women have increasingly been reported in news media, since the 2012 'Nirbhaya' incident took place. Recently the number of 'women-centric' films is steadily increasing. In the present film review, I analyze three recent films- Naa Bangaaru Talli (2014), Mardaani (2014) and Lakshmi (2014), which engage with the issue of sex trafficking, to understand the depiction of women's vulnerability and agency with respect to gender-based violence. Though the films portray sex trafficking and their related issues in a realistic manner, none of these films move on to portray the next phase of rehabilitation and reintegration of victims. I also explore the extent to which
\end{abstract}


the films emphasize the importance of individual resilience versus social enabling factors for overcoming sex trafficking. Finally, the paper speculates on the potential impact of these films on viewers.

\section{KEYWORDS}

Sex Trafficking, Vulnerability, Victimhood, Rehabilitation

\section{INTRODUCTION}

The last few years have seen a spate of 'issue-based' commercial films in India, dealing with problems ranging from farmers' suicide to female infanticide. In the aftermath of the 2012 'Nirbhaya' incident, crimes against women have taken center-stage in mainstream media and the number of 'women-centric' films is steadily increasing. At the same time, most of these films depict the triumph of the individual heroine over social adversity, thus eliding questions about the structural nature of gender-based violence.

One of the most poignant forms of organized crimes against women, which has rarely made it to the world of Indian cinema as the focal theme, is that of sex trafficking, i.e. the forcible involvement of women in the flesh trade (Hughes 2005). Majority of the survivors of sex trafficking are illiterate, poor, from rural areas, and married off at a very young age. They typically undergo considerable violence, including physical and sexual abuse, in the process of trafficking, irrespective of variation in their nationality, caste, creed and religion (Dartnall and Jewkes 2013; Sen and Nair 2002-2003; Thilagaraj 2010; Modi, Palmer and Armstrong 2013; Vindhya and Dev 2011; Simister and Makowiec 2008) to say nothing of stigma and discrimination after rescue and rehabilitation. In the space of Indian cinema, much of the spotlight has been on the sensational drug trafficking and gang mafia of Bombay. Given the gravity of sex trafficking as a human rights issue, it is therefore refreshing to see three recent films on the focal theme of sex trafficking - Naa Bangaaru Talli (2014), Mardaani (2014) and Lakshmi (2014).

While sexual violence in the form of rape and kidnapping is a common theme in mainstream 'masala' Bollywood films as a sensational element, the sensitive portrayal of crimes against women is rare. During my own research (which is a part of my doctoral dissertation) on sex trafficking, the rehabilitated women I interviewed often expressed strong criticism about mass media's naïve portrayal of prostitutes as money-minting, happy and sexually driven women. They argued that this unrealistic portrayal ignored the fact that this was not a reality for the majority of trafficked women. Therefore, the arrival of three recent mainstream movies related to sex trafficking, from awardwinning directors sparked my curiosity to explore the movies' portrayal of the everyday reality of trafficking for women.

\section{RESEARCH QUESTIONS}

This paper undertakes a review of these three films, keeping in mind the following research questions:

- How are questions of women's agency and vulnerability in relation to sex trafficking engaged with in these movies?

- What, according to the films, are the factors required for coming out of trafficking? Do the films emphasize individual courage/resilience of survivors or social enabling factors?

- What kinds of solutions for the problem of sex trafficking are portrayed in the films?

\section{METHODS: FILM ANALYSIS}

Qualitative research methods are increasingly being used in psychology, with the contemporary shift away from positivist approaches and the turn towards social constructionism. Film analysis is a method of analysis that is increasingly being used to understand the representation of psychological issues in the media (see, e.g. Varma 2011). Film analysis aims to question the portrayal of reality and depict the social construction of the issue being portrayed in the film. It also explores the audience reactions to the issues depicted in the films (Flick 2009; Denzin 2004). In analyzing the three films, I followed the guidelines outlined by Flick (2009) and Denzin (2004) which involved viewing the movies, writing down the research questions related to the movies, describing each movie and analyzing it by comparing the movies and by comparing it to my own findings from my Ph.D. research with survivors of sex trafficking.

\section{DISCUSSION}




\section{[I] Background information about the films}

\section{Lakshmi (2014): Courage of the survivor}

Lakshmi is a film written and directed by Nagesh Kukunoor, who is known for his movies that portray social issues and relationship issues. He is also an acclaimed actor and has played the role of the pimp called Chinna in Lakshmi (2014). The role of Lakshmi is done by Monali Thakur.

The film follows a fourteen year old girl who was trafficked and eventually rescued by an NGO who stood with her against the traffickers. The film aims to provide a glimpse into the experiences of forced prostitution and the difficult process of rescue and rehabilitation of the victim.

\section{Mardaani (2014): Courage of the police}

Mardaani is written by Gopi Puthran and directed by Pradeep Sarkar, known for movies portraying relationship issues. The main cast of the film involves Rani Mukerji as Shivani Shivaji Roy (the police woman).

This film, based on a true story, is about an honest female police officer who strives to rescue and rehabilitate a street girl from the dangers of sex trafficking. She takes a personal interest in the girl, considering her as her own daughter. The focus of this film is the difficulties the police experience while rescuing the sex trafficked from the trap of prostitution.

\section{Naa Bangaaru Talli (2014): The entangled life of a trafficker and his daughter}

Naa Bangaaru Talli is a film written and directed by Rajesh Touchdriver, who is also known for films portraying social issues. The role of Durga is played by Anjali Patil and her father's role (the pimp's role) is played by Siddique. ${ }^{4}$

The film is about a young lady Durga and her father Srinivas. Her father was a pimp by profession, which she was unaware of and comes to know only after she was sex trafficked by her father's boss Reddy. She used to be very proud of her father, but was shocked and ashamed to learn the truth.

\section{[II]The Agency of the Victim}

The films effectively creates awareness about the social issue of sex trafficking through its portrayal of the following aspects: the nature of the organized crime of sex trafficking; the vulnerability of girls due to their unstable family structure riddled with problems of alcoholism; the challenge of fighting trafficking and escaping. Most importantly, it depicts the lifestyle in a brothel, where myths about HIV continue to play a role in prostitution and trafficking. The agency of the victims in the films keep varying depending on their stage of trafficking, their family background and their reactions to these situations.

\section{(1)The overall background of the victim}

In the movie Lakshmi, the victim Lakshmi's family consists of her alcoholic father and two younger sisters, her mother having passed away in her childhood. They live in a slum area. The girls received no education, coming from a poor family. Financial situation of the family leads her father to sell Lakshmi at the age of 14 years.

In the movie Mardaani, the victim (Pyaari) is a girl saved by the protagonist from a railway station before she was about to be sold by her own uncle. Neither the protagonist nor the girl knows her age or other details. No whereabouts of the parents are mentioned; it is therefore suggested that she was orphaned and the protagonist policewoman Shivani then had admitted the girl (Pyaari) to a shelter home run by an NGO. In all the scenes with the protagonist the victim is a very grateful child who almost worships the protagonist.

In the movie Naa Bangaaru Talli, the victim Durga is the only child of her parents who are financially sound. Her father is a pimp, but she and her mother are unaware of this, believing that he works in an NGO which helps girls in getting jobs in the city and abroad. Durga is a very bright student and wants to pursue higher education. The father tries to dissuade her from going to the city to study. Without his knowledge, she posts her application for a college in the city. Durga is looked upon as trouble by her villagers because she always tries to fight for girls who are victims of child sexual abuse in her vicinity. She is mocked for one such attempt by the parents of a sexually abusive 
boy. The stigma of raising such issues in her village keeps the parents of victimized girls from complaining against such acts.

Naa Bangaaru Talli also breaks through the myth of being safe from being trafficked if one is educated, unlike the other two films, which do not even bring the concept of education in them.

\section{(2)The reaction of the victims to being trafficked}

Lakshmi attempted to run away, sensing that something was not right, but she was forcibly restrained by Chinna, who abused her physically and verbally. Lakshmi tries to escape thrice but is caught and beaten up or wounded with weapons and forced to service more customers. Swarna repeatedly warns Lakshmi against escaping, pointing out that it was in vain as she would eventually be caught and punished even more severely. Lakshmi, being brave, still tries, and faces the consequences. My interviews with survivors also found that majority of them tried to escape but were unable to because of the lack of support.

While fear is the only reaction Pyaari portrays, till she is encouraged to do a group attack on her trafficker and portrays her anger, Durga arrives at the house of the trafficker and feels uncomfortable but goes in and finds herself trapped. Once when she tries to escape, she contacts the police but the police only take her back to Reddy, who they are already familiar with. The film also shows the policeman raping her.

The last portion of the movie is focused on the difficulty in getting back to her house. All through the journey and even after reaching home, Durga the confident girl is shown as a weeping person who only follows her fiance's instruction. She is unable to even speak with her own mother, so affected is she by the trauma and tragedy she faced in her life. The movie ends with the death of Srinivas, who commits suicide after his own daughter was sex trafficked by his boss. Ultimately, Durga rejects him by spitting on his face.

\section{(3)The rescue and rehabilitation of the victim}

What is most significant is the portrayal of the rescue and rehabilitation of the victim, which emerges as something that is possible, though difficult. This also counters the dominant conception that most sex workers tend to return to sex work and that very few become truly rehabilitated. In fact, the film also shows that while many of the girls chose to go back to the familiar, though painful, life in the brothel, which was the only life they had known, Lakshmi chose to leave. Finally, the film leaves one feeling sad about the violence these women and girls suffer, while at the same time offering the hope of rehabilitation.

There is a female NGO worker, Uma didi, who regularly visits to distribute condoms (along with chocolates!) to this brothel. She is friendly with all the inmates and finds out more information about their personal details. There is another small boy (Chotu) who buys alcohol and other items for the brothel inmates, since they are restrained behind a wall. (Scenes of Chotu passing the items over the wall every now and then are suggestive of prisons within which the inmates are confined.) Lakshmi was eventually rescued by the NGO and the police, with the support of the brothel madam Jyoti who took pity on her when she became severely injured from the abuse and allowed the NGO worker entry into the brothel, paving the way for her rescue. An NGO worker Mohan comes to save her disguised as a customer. He fits a camera in the girl's room with the aim of filming her abuse and victimization as evidence for the case. A police raid is carried out with the NGO's support. Lakshmi and all her brothel inmates are then moved to a shelter home run by the same NGO. In my research I found that in some cases, actual customers rescued the victims and ended up either living with them or financially providing for them.

All the girls eventually willingly go back to the brothel except for Lakshmi. Jyoti goes back to sex work the moment Lakshmi's health is stable because she has to earn to educate her daughter. Swarna in one scene tells her that she is unable to get any other job and that she is molested wherever she goes seeking a job. She also tells Lakshmi that her market rate will be there only for another few years. After her rate goes down, she would consider less paying jobs like basket making, etc. which the NGO provides for rehabilitation. This also calls into question the effectiveness of the livelihood options provided by NGOs, a point that was mentioned by survivors in my research and Crawford's (2010) research in Nepal as well.

The last portion of the movie emphasizes the difficulty in getting a lawyer to fight her case in court. The film also brings out the re-traumatizing that the victim undergoes during the cross-examination in the courtroom. The opposition lawyer effectively blames the victim for getting involved in sexual behavior at a very young age. His use 
of the words 'sex' and 'rape' interchangeably, making it sound like it was a case of a woman having a 'bad character'. The movie ends with Lakshmi winning the case and getting all those who were responsible for her trafficking punished.

Mardaani clearly ends with dramatic flourish, where the police woman emerges as a heroine who succeeds in her fight against evil. At the same time, such a 'rescue' process depicted departs considerably from reality. In my own research with women who had been rehabilitated from sex trafficking, I had never encountered such a rescue process. The film clearly makes Shivani the central protagonist emerges as a heroine. Yet, given that Shivani's fight against the crime is depicted as her personal vendetta, it raises questions as to how realistic such a 'rescue' process is. The fact that Pyaari's rescue rests on the individual initiative of a staunch supporter in fact is a drawback of the film as the 'war against trafficking' is depicted as a personal war. This is clearly reflected in the film's tagline 'every war is personal'.

Yet, this raises the question as to what solution does the film offer for dealing with organized gender crimes such as trafficking. Does the solution lie in waiting for heroes or heroines to take up the cause against the issue? Does the film not seek to bring about structural and systemic change in the police and judiciary? Why does the film not place accountability on the state? These questions inevitably come to one's mind.

Finally, the fact that Pyaari's rescue is achieved by a go-getter policewoman who is striking for her 'masculinity' seems to suggest that it is only through this 'aggressive masculinity' that women can fight gender injustice. At the same time, the film also portrays the issues that the police face while handling crimes like sex trafficking, an issue that has generally been under-represented in the media.

At her friend's wedding, Durga meets her friend's elder brother Vijay and they eventually fall in love and get engaged. The rescue by a lover turned husband in Durga's story was also found in my research in one of the cases. Durga is secretly and tactfully escorted by her fiancé (Vijay) who found her being chased by the guards of the hotel. The father finally sees her escaping with Vijay and he gets back home.

This rescue process by the fiancé or a lover depicts reality when compared to a few cases in my own research with women who had been rehabilitated from sex trafficking, where they were rescued by either a customer or a lover or a husband. This highlights the gender hierarchy and the struggle of a single unaffiliated woman in the Indian society, even in the present era.

Yet, this film raises the question as to what would lie in wait for this survivor after this rescue and the death of her father/ trafficker. The probability of this kind of an ending to a trafficker is questionable considering the patriarchal system in our society. In fact, in many cases, young girls are sold into trafficking by their own parents. The other question that inevitably comes to one's mind is the difficulty in identifying a trafficker, because of their dual lives and dual personalities.

The movie portrays the experience and the rescue of the victim of sex trafficking Durga trapped due to her father's reputation and rescued by her fiancé. The filmmaker would have wanted the audience to take home a message to women to fight against this organized crime, even if close ones are involved in this crime.

\section{[III] Description of the traffickers, the pimp, the brothel owner and other victims}

In the movie Lakshmi, Lakshmi was sold to a rich, well-dressed woman (Radha), who pays her father Rs. 30,000. Radha bargains with the pimp (Chinna) about the price for the girl. Chinna eventually buys Lakshmi for the price of Rs.50,000. Chinna and his brother Reddy are depicted as the rich and vindictive pimp and trafficker who have a doctor inject hormones into Lakshmi to instigate the growth of secondary sexual characteristics in her. The film also portrays the prevalent myth that having sex with a virgin can cure HIV/AIDS, Reddy having raped her for this purpose. This was her first rape, following her previous experiences of abuse. The trafficker (Reddy) is a rich man in the society and when the case is filed against him, he tries to bribe Lakshmi. Radha tries to dissuade Lakshmi from fighting her case, by telling Lakshmi that there is no scope of rehabilitation and reintegration for her.

When she is moved into the brothel, Lakshmi slowly adapts and becomes a sex slave. A prostitute roommate, Swarna, (who is older and has been in the brothel for a longer time) befriends Lakshmi and teaches her how to dress up, solicit customers, and survive through recourse to alcohol. Drawing on her own failed attempts to escape this slavery, she perhaps felt that she was helping Lakshmi to 'cope'. 
On one occasion, when she escapes she reaches the police station to lodge a complaint but the police in turn call the pimp (Chinna), whom they are friendly with, and have her sent back to him. This illustrates how the police are such an integral part of the system of trafficking, that a victim is rarely ever able to fight the organized crime of trafficking by herself.

The power structures and the psychologically coercive patterns that support the crime of trafficking are vividly portrayed in the film. The film also succeeds in portraying the character of the brothel madam (Jyoti) in a nuanced manner, where she emerges as both violent and caring at the same time. For instance, in one scene Jyoti is portrayed as a loving mother who is engaged in sex work only for her daughter's sake. This is contrasted in another scene where she brutally murders the pimp. While Jyoti is mostly harsh, she does help Lakshmi out, particularly when Lakshmi's health ailments increase.

Pyaari's ordeal began when she was kidnapped from the NGO's shelter home and locked up with other girls. Their clothes were torn off and they were given a common bath (like cattle). They are then given towels to wipe and forced to strip in front of the trafficker (Walt) so that they could be assessed on their suitability for different types of customers. Walt harshly deals with a girl who refuses to strip and threatens to kill her. This one event makes the path towards psychological coercion easier for the trafficker. The girls are all in their teenage years and unable to fight the traffickers.

The trafficker Walt warns the Protagonist in Mardaani, to stay away and not get involved in this case's investigation. Her husband is a doctor, whose reputation is tainted in an attempt to warn her from investigating the case further. Her husband in spite of this supports her to fight the trafficker and find the girl.

This part of the film brings out the cold-blooded character of Walt, a tech-savvy college dropout in his mid-twenties who is the mastermind behind the racket. He is shown playing violent video games on his tablet. In order to avert the investigation, Walt has all those caught by the police systematically killed off, so that no information is obtained. Every time Shivani gets a step closer to the investigation, Walt tries to prevent her from proceeding with the investigation. (One particularly gruesome scene involved him cutting off Pyaari's finger and sending it to Shivani with a warning). In another scene, he deals with the illness of a trafficked victim by having her shot.

In depicting the hurdles to investigating sex trafficking cases, the film portrays how Shivani was dissuaded from the investigation by the police department who argued that she was getting 'too involved' or 'too emotional' about the case. Such remarks also reflect sexist notions about the tendency of professional women to be 'swayed by their emotions'. Other strategies for discouraging the investigation included telling Shivani that the case was no longer under the jurisdiction of the crime branch, but was an anti-trafficking case. Such bureaucratic hurdles did not however stop Shivani, who resolved to solve the case in 30 days. Clearly, the film was employing dramatic elements from the genre of action movies. It suddenly shifted gears, with a chase scene and fight sequences between Shivani and the villains.

In one of the final scenes of the film, she finds the trafficker's house, and goes in by herself, only to be caught by the traffickers. Walt attempts to trade Shivani to a political V.I.P. Shivani, however, retorts that being caught was part of her plan. This is followed by a long sequence of fist fights between Shivani and the traffickers. The movie ends with her fighting Walt single-handedly, and encouraging the group of trafficked girls including Pyaari, to join in the fight. Eventually, the film ends with the arrest of all the criminals and the mastermind Walt being killed by the heroine.

In Naa Bangaaru Talli, the trafficker Reddy thinks that Srinivas (the pimp) is doing his own business secretly with a new sex trafficking victim and gets a prostitute to coerce her to go with her to meet Srinivas. The brothel madam tries to coerce Durga to cooperate by telling her that she and many others are victims of sex trafficking, trafficked by her father. She also every now and then shows her some wounds and makes her feel guilty for the lives her father has spoilt. Durga is forced to attend to customers. Meanwhile the father continuously searches for his lost daughter for days but does not find her. Reddy and this brothel madam made her solicit an international customer who was about to kill Durga. In an attempt to save Durga, the brothel madam hit the customer and ran out with Durga, hiding from the guards.

Naa Bangaaru Talli unravels the complications faced by a trafficker, who finds his own daughter caught in a similar trap on his account. The trafficker's committing of suicide in the end of the movie portrays the predicament that criminals sometimes find themselves in due to their dual lives and attempt to hide the truth of their hidden criminal life from their loved ones. It also shows that Srinivas was a loving father at one side and a tough trafficker on the 
other hand and the sex trafficking of his daughter collapsed him into the former role, as a heartbroken father searching for his missing daughter and blaming himself for her going missing.

\section{CONCLUSION}

One of the primary strength of all the three movies is that they are based on true stories and are all aimed at bringing awareness about the issue of sex trafficking, which is a rising social evil in Indian society. Therefore the movies are more realistic in the content, making the impact more powerful.

Although the films are very different, there are certain similarities across them. In all the movies, the pimps who were immediately in-charge of the trafficked girls were playing roles which were harsh and kind intermittently. (In some of the cases I interviewed in my own research, I had also found similar findings regarding the behavior of the pimps.) Some have referred to this behavior as a kind of psychological coercion, which lures victims to co-operate with traffickers, without any rebellion. Hopper and Hidalgo (2006) describe how traffickers use physical and psychological forms of abuse and psychological coercion to convince the victims to trust them. Yakushko (2009) identified the following range of reactions in victims caused by such psychological coercion: fear, guilt, rage, sense of betrayal, distrust, helplessness, shock, suspicion and feeling lost. This was evident by the expressions of all the trafficked victims in the movies. The sex trafficked women often suffer from depression, self-blame, anger and sleep disturbances (Hopper and Hidalgo 2006; Crawford and Kaufman 2008).

The films also displayed the gruesome violence and abuse by the traffickers, which made the trafficked submit easily. One of their favorite forms of violence was beating or wounding the trafficked or forcing them to attend to more customers. The sex trafficked victims invariably get abused physically and sexually, directly or indirectly by their traffickers and customers before being trafficked, while being trafficked and after being trafficked too. The widespread use of physical and sexual abuse in trafficking was also found in my own study. Since the movies were focused on teenage victims of sex trafficking the concept of the domestic violence due to alcohol abuse in their marital family was never emerging in these films, which was observed in some of the survivors I interviewed. The reviewed movies did not focus on child abuse- physical, verbal or sexual - in the natal families before trafficking, which was also seen in my study.

Perhaps the most important achievement of the films was the portrayal of the intricacies and nuances of the process of trafficking, which has largely remained a hidden mystery for the general public. For instance, in depicting the transportation of the trafficked into unknown places, the difficulty of survival in the brothel, the power structures within the brothel, and the strategies of coercion employed by traffickers, the films offer a valuable insight into the 'life of a trafficked victim'. The films also subtly portray the networks between the police, the NGO and the trafficked. Trafficking thus emerges as a complex socio-economic and political issue. It is finally only the presence of social support, provided either through NGO workers or the police, or some individual who cares for the victim, which makes rescue possible.

In all the movies, the sex workers who were immediately in-charge of the trafficked girls were playing roles which were harsh and kind intermittently. (In some of the cases I interviewed they seemed to have behaved similarly which suggests a realistic portrayal of the same.)

At the same time there are limitations in the films. Rehabilitation and reintegration of victims is a very complex and important process for the victims of sex trafficking (Crawford 2010). None of the three films move to portray the next phase of rehabilitation and reintegration of victims. In fact, research on rehabilitation is also limited, with some pessimistic findings that many individuals often get re-trafficked or go back to sex work (which was briefly shown in the end of the film Lakshmi). The process of reintegration of the victim is often challenging due to the stigma, which media contributes towards. Other researchers (Harrington 2005; Hameed, Hlatshwayo, Tanner, Turker and Yang 2010; Pandey,Tewari and Bhowmick 2013; Weitzer 2007) have found that victims continue to experience stigma and discrimination from society during their reintegration, issues which have been left out by the films. Though the three movies reviewed are focused towards raising social awareness, since they do not depict the acceptance, rehabilitation and reintegration of the victims into family and society, it is questionable as to what extent they are effective in de-stigmatizing the issue of sex trafficking. Including this phase of rehabilitation would have provided a more complete picture of the complexity of the problem of trafficking.

\section{NOTES}


1. Satish Kaushik is Reddy the elder brother of Chinna, the one who runs the brothel. Gulfam Khan acts as Radha, Shefali Shah acts as Jyoti (the brothel madam), Vinita Joshi acts as Asha (Jyoti's daughter) and Flora Saini acts as Swarna (Lakshmi's brothel roommate-cum friend-cum-teacher. Priyanka Vir (Uma didi) and Ramkrishna Shenoy (Mohan) are the Non-Governmental Organization (NGO) workers, Ram Kapoor acts as the Lakshmi's lawyer Avinash and the opposition lawyer is played by Sumit Sharma.

2. The word 'didi' is a Hindi kinship term used to refer to an older sister.

3. Other supporting actors include Tahir Raj Bhasin as Walt (a) Karan Rastogi (the trafficker and the mastermind of the process), Anil George as Vakeel (the senior trafficker), Jisshu Sengupta as Dr. Bikram Roy (Shivani's husband), Priyanka Sharma as Pyaari (the sex trafficked girl), Avneet Kaur as Meera (Shivani's neice), and Mona Ambegaokar as Meenu Rastogi (the brothel owner, a sex worker and Karan's mother).

4. The other main actors include Anoop Aravindan as Reddy (the trafficker), Neena Kurup as Durga's Mother and Rathna Shekar Reddy as Vijay (Durga's fiancé).

\section{REFERENCES}

Crawford, M. (2010). Sex Trafficking in South Asia: Telling Maya's story. London: Routledge.

Crawford, M., \& Kaufman, M.R. (2008). Sex trafficking in Nepal : survivor characteristics and long-term outcomes. Violence Against Women, 14(8), 905-916.

Dartnall, E., \& Jewkes, R. (2013). Sexual violence against women: The scope of the problem. Best Practice \& Research Clinical Obstetrics and Gynaecology, 27, 3-13.

Denzin, K.N. (2004). Reading Film: Using Films and Videos as Empirical Social Science Material. In Flick, U., von Kardorff, E. \& Steinke, I. (Eds.), (pp. 237-242). A Companion to Qualitative Research. London: Sage.

Flick, U. (2009). An Introduction to Qualitative Research, 4th ed. Los Angeles: Sage Publications.

Hameed, S., Hlatshwayo, S., Tanner, E., Turker, M., \& Yang, J. (2010). Human trafficking in India: dynamics, current efforts, and intervention opportunities for the Asia foundation. Stanford: Stanford University.

Harrington, C. (2005). The politics of rescue. International Feminist Journal of Politics, 7(2), 175-206.

Hopper, E., \& Hidalgo, J. (2006). Invisible Chains: Psychological Coercion of Human Trafficking Victims. Intercultural Human Rights Law Review, 1, 185-209.

Hughes, D. M. (2005). The Demand for Victims of Sex Trafficking. http://www.uri.edu/artsci/wms/hughes/demand_for_victims.pdf

Modi, M. N., Palmer, S., \& Armstrong, A. (2013). The role of violence against women act in addressing intimate partner violence: a public health issue. Journal of Women's Health, 1-7.

Pandey, S., Tewari, H. R., \& Bhowmick, P. K. (2013). Antecedents and reintegration of sex trafficked victims in India: a conceptual framework. International Journal of Criminal Justice Sciences, 8(1), 47-62.

Sen, S., \& Nair, P. M. (2002-2003). A Report on Trafficking in Women and Children in India. Institute of Social Sciences, National Human Rights Commission and UNIFEM (2004), http://nhrc.nic.in/Documents/ReportonTrafficking.pdf.

Simister, J., \& Makowiec, J. (2008). Domestic violence in India: effects of education. Indian Journal of Gender Studies, 15(3), 507-518.

Thilagaraj, R. (2010). Trafficking and HIV : Vulnerabilities, Linkages and Responsibilities. Chennai: Kardoba Kansultancy. 
Varma, S. (2011). Disability through the lens of the movie I am Sam, Hollywood Production, 2001. Psychology and Developing Societies, 23(2), 297-305.

Vindhya, U., \& Dev, V.S. (2011). Survivors of sex trafficking in Andhra Pradesh: evidence and testimony. Indian Journal of Gender Studies, 18(2), 129-165.

Weitzer, R. (2007). The social construction of sex trafficking: ideology and institutionalization of a moral crusade. Politics Society, 35, 447- 476.

Yakushko, O. (2009). Human trafficking: a review for mental health professionals. International Journal for the Advancement of Counselling, 31, 158-167. 